\title{
SISTEM REKOMENDASI DESTINASI WISATA DI KOTA KUPANG DENGAN METODE WEIGHTED PRODUCT
}

\author{
Marlinda Vasty Overbeek ${ }^{1}$, Remerta Noni Naatonis ${ }^{2}$ \\ ${ }^{1}$ Program Studi Informatika Fakultas Teknik dan Informatika Universitas Multimedia Nusantara \\ Email : marlinda.vasty@umn.ac.id \\ ${ }^{2}$ Program Studi Sistem Informasi STIKOM Uyelindo Kupang \\ Email : reyheka@gmail.com
}

\begin{abstract}
From 2006 to the latest data collection in 2017, the number of domestic and foreign tourists visiting East Nusa Tenggara is increasing. In Kupang city as the provincial capital of East Nusa Tenggara. Kupang City is not just a temporary stop when tourists want to transit to other islands in East Nusa Tenggara but have become tourist destinations. The increasing number of tourist visits is not accompanied by a system of recommendations about tourist destinations in the city of Kupang, In this study a recommendation system was built in Kupang City using the weighted product method, which is one of the techniques of Multiple Alternative Decision Making. Weighted products use multiplication to connect attribute ratings. The criteria used in this study are 3 criteria, namely costs, facilities provided and reviews from previous visitors. While for locations or tourist destinations there are 55 tourist destinations in Kupang City which are the alternatives in this study. From the results of the study, for natural attractions, Namosain Beach ranked first to be visited with a value of 0.00519. As for artificial tourism objects, Nostalgia Park is the first place with a value of 0.0805. As for culinary tourism, Nostalgia Park culinary ranks first at 0.0904.
\end{abstract}

Keywords:: Tourist Destinations, Multiple Alternative Decision Making, Recommendation Systems, Decision Support Systems, Weighted Products

\section{PENDAHULUAN}

Pulau Timor adalah salah satu pulau yang ada di Nusa Tenggara Timur terdiri dari tiga Kabupaten, yaitu Kabupaten Kupang, Kabupaten Timor Tengah Selatan, Timor Tengah Utara dan satu Kota Madya, yaitu Kota Kupang. Di Pulau Timor memiliki destinasi wisata alam, wisata kuliner, wisata budaya dan sejarah yang paling banyak di Nusa Tenggara Timur. Dari catatan Badan Pusat Statistik Nusa Tenggara Timur (BPS NTT), untuk jumlah wisatawan domestic pada tahun 2017 sebanyak 523083 jiwa dan wisatawan mancanegara sebanyak 93455 jiwa [1][2]. Banyaknya jumlah wisatawan di Indonesia tidak terlepas dari banyaknua event wisata, pembenahan obyek wisata unggulan, pembenahan infrastruktur dan fasilitias penunjang.

Meskipun semakin meningkat, namun para wisatawan masih kebingungan untuk daerah wisata yang ada di Nusa Tenggara Timur, khususnya di Kota Kupang. Kurangnya informasi tentang tempat wisata dan tidak adanya sistem yang memberikan rekomendasi tempat wisata membuat wisatawan baik domestic dan mancangera tidak mengetahui wisata apa saja yang ada di Kota Kupang.

Pada penelitian ini di fokuskan pada pemberian rekomendasi destinasi wisata yang ada di Kota Kupang sebagai ibukota dari Nusa Tenggara Timur. Kota Kupang sebagai ibukota provinsi memiliki sarana pendukung pariwisata terutama bandara dan pelabuhan. Wisatawan atau tamu yang datang di Nusa Tenggara Timur sebagian besar akan menjajaki Kota Kupang, karena semua penerbangan local akan singgah di Bandara El Tari Kupang. Karena posisi Kota Kupang tersebut akan menjadi modal utama dalam memperkenalkan objek wisatanya kepada wisatawan atau tamu yang akan berkunjung melalui suatu sistem rekomendasi tempat wisata kepada wisatawan yang lebih efisien dan efektif.

Oleh karena itu sistem rekomendasi ini diharapkan dapat membantu dalam memberikan rekomendasi kepada wisatawan domestikmaupun mancanegara tentang tempat wisata yang ada di Kota Kupang. Bukan hanya singgah untuk penerbangan lanjutan atau transit, namun akan wisatawan akan 
berkunjung ke tempat-tempat atau destinasi wisata yang ada di Kota Kupang.

Sistem rekomendasi dikembangkan dengan sistem pendukung keputusan dengan menggunakan weigted product yang merupakan salah satu teknik dari Multiple Attribute Decision Making (MADM). MADM adalah suatu metode yang digunakan untuk mencari alternatif optimal dari sejumlah alternatif dengan kriteria atau pengukuran tertentu. Inti dari MADM adalah menentukan nilai bobot untuk setiap atribut, kemudian dilanjutkan dengan proses perangkingan yang akan menyeleksi alternatif yang sudah diberikan.

Weighted Product sudah banyak digunakan dalam berbagai penelitian. Misalnya pada penelitain Rani [3], dilakukan penelitian untuk memberikan solusi terhadap pemilihan sepeda motor. Sari, et al [4] juga melakukan penelitian dengan persentase penilaian sebesar $90 \%$. Hal ini menyatakan sistem pendukung keputusan tersebut sangat baik untuk dijadikan pendukung keputusan dalam penentuan destinasi wisata yang ada di Kota Kupang.

Dari uraian yang sudah disampaikan, maka dari penelitian ini memiliki tujuan untuk merancang, membangun dan mengimplementasikan suatu sistem pendukung keputusan yang dapat memberikan solusi berupa rekomendasi destinasi wisata di Kota Kupang dilihat dari kriteria biaya, fasilitas yang disediakan, dan review pengunjung yang sudah pernah datang di tempat tersebut. Sedangkan untuk alternative atau pilihan dari sistem adalah 55 lokasi wisata yang ada di Kota Kupang, yang terbagi atas 27 obyek wisata alam, 15 obyek wisata buatan dan 13 obyek wisata kuliner.

\section{METODE PENELITIAN}

\section{a. Dasar Weighted Product}

Metode dari weighted product secara singkatnya adalah sebagai berikut [5] :

1. Mengalikan seluruh atribut bagi seluruh alternatif dengan $W$ (bobot) sebagai pangkat positif untuk atribut keuntungan atau bernilai negative untuk atribut biaya.

Perbaikan bobot $\sum W_{j}=1$ adalah menggunakan rumus sebagai berikut :

$$
W_{j}=\frac{W}{\sum W}
$$

2. Hasil perkalian dijumlahkan untuk menghasilkan nilai pada setiap alternatif
Variable $W$ adalah pangkat bernilai positif untuk atribut keuntungan dan bernilai negative untuk atribut biaya. Preferensi untuk alternatif $S_{i}$ diberikan sebagai berikut

$$
S_{i}=\prod_{j}^{n} x_{i j}^{w j}
$$

Dengan $i=1,2, \ldots, m$ dan $\mathrm{j}$ sebagai atribut $=1,2, \ldots, n$.

Keterangan :

$\mathrm{Si}$ : skor atau nilai dari setiap alternatif $X i j$ :nilai alternatif ke- $i$ terhadap atribut ke $-j$

$W j$ : bobot dari setiap atribut atau kriteria

$n$ : banyaknya kriteria

3. Membagi nilai $V$ bagi setiap alternatif dengan nilai total dari semua nilai alternatif

Untuk mencari alternatif terbaik dilakukan dengan persamaan berikut :

$V_{i}=\frac{S_{i}}{\prod_{j=1}^{n}\left(X_{j}^{*}\right)^{w j}}$

Dimana :

$V:$ preferensi alternatif dianalogikan dengan vector $v$

$X$ : nilai kriteria

$W$ : bobot kriteria / sub kriteria

$i$ : alternatif

$j$ : kriteria

$n$ : banyaknya kriteria

* : banyaknya kriteria yang telah dinilai pada vector $S$

4. Ditemukan urutan alternatif terbaik yang akan menjadi keputusan

\section{b. Prosedur Penelitian}

Sistem rekomendasi tempat atau destinasi wisata di Kota Kupang dengan algoritma Weighted Product dimulai dari studi literature lalu dilanjutkan dengan identifikasi masalah. Sumber pengetahuan ditentukan untuk dapat mengakuisisi pengetahuan dan merepresentasikannya. Tahapan selanjutnya adalah pengembangan mesin inferesnsi, implementasi dan pengujian sistem. Tahap prosedur penelitian dapat dilihat pada gambar 1. 


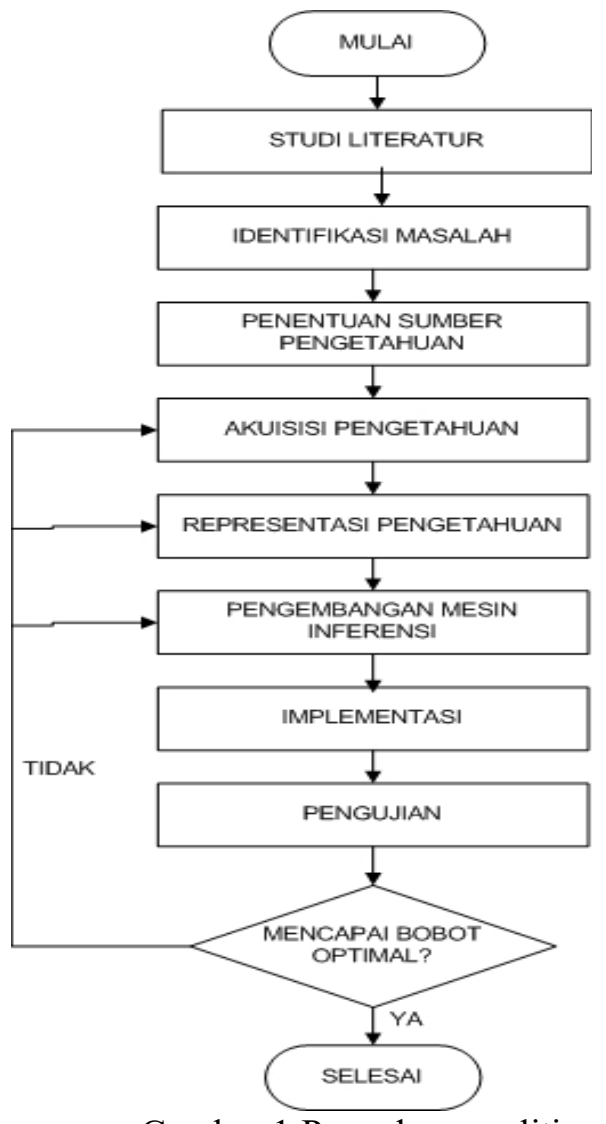

Gambar 1 Prosedur penelitian

Langkah dari prosedur penelitian dijelaskan sebagai berikut :

1) Studi literatur

Pada tahap ini dikumpulkan informasi dan mempelajari materi serta sumber data yang diperlukan untuk membangun sistem metode Weighted Product berdasarkan kriteria yang telah diberikan

2) Identifikasi masalah

Masalah sistem rekomendasi tempat atau destinasi wisata dipersempit hanya untuk sistem rekomendasi di Kota Kupang lalu ditentukan kriteria atau pengukur serta alternatif yang mempengaruhi

3) Penentuan sumber pengetahuan Sumber pengetahuan adalah Dinas Pariwisata Kota Kupang. Dalam hal ini adalah 1 orang pakar sebagai sumber

4) Akuisisi pengetahuan

Proses ini dilakukan melalui diskusi, wawancara kepada pakar, dan akuisisi sumber literature dan konfirmasi. Pada tahap ini, hasil yang diberikan adalah diketahui kriteria yang mempengaruhi dan juga alternatif sebagai pilihan destinasi wisata di Kota Kupang.

5) Representasi pengetahuan
Setelah dilakukan akuisisi pengetahuan maka pengetahuan akan direpresentasikan. Hal ini dilakukan dengan membangun table berpasangan antara kriteria dan alternatif.

6) Pengembangan mesin inferensi Pada tahapan ini dilakukan pengembangan model dengan Weighted Product. Penggambaran pengembangan mesin inferensi atau mesin pengambilan keputusan dengan tahapan sebagai berikut :

a. User akan memasukkan bobot dari tiap kriteria

b. Penghitungan nilai untuk alternatif $A$

c. Penentuan perangkingan alternatif, dimana nilai $V$ yang terbesar adalah alternatif terpilih dan menjadi alternatif terbaik

7) Implementasi

Setelah selesai pengembangan mesin inferensi, baru dilakukan implementasi dengan menggunakan Bahasa pemrograman. Disini dikembangkan dengan Bahasa pemrograman Matrix Laboratory atau MatLab.

8) Pengujian

Pengujian dilakukan dengan menguji hasil yang diberikan oleh sistem diujikan kepada hasil yang sudah ada dari pakar. Pengujian ini dilakukan untuk memvalidasi hasil keluaran tentang penentuan optimalitas hasil keluaran atau output dari sistem. Tujuan dari tahapan ini adalah memeriksa apakah sistem pengambilan keputusan sudah optimal atau tidak jika ada perubahan. Dari pengujian akan diketahui berapa error dari sistem yang telah dibangun. Pengujian yang dilakukan adalah analisis sensitivitas dari sistem dengan menurunkan bobot kriteria tiap wisata sebanyak 10 poin untuk 5 besar wisata yang terpilih masing-masing.

\section{HASIL DAN PEMBAHASAN}

Pada penelitian ini dilakukan perangkingan untuk mengetahui pemilihan tempat wisata atau destinasi wisata yang ada di Kota Kupang dengan menggunakan weighted product. Dari hasil penelitian pada 3 kriteria dan 55 destinasi wisata (27 wisata alam, 15 wisata buatan dan 13 wisata kuliner), didapatkan hasil perangkingan sebagai berikut. 
Adapun sistem dikembangkan dengan Bahasa Pemrograman Matrix Laboratory (MatLab) R2010.

Setelah dilakukan perangkingan dengan weighted product, maka didapatkan 5 posisi teratas dari tiap destinasi wisata, baik wisata alam, buatan maupun kuliner. Pada wisata alam, posisi pertama ditempati oleh Pantai Namosain (0.0519), diikuti oleh Pantai Subasuka (0.0519), Mata Air Oelon (0.0471), Gua Monyet alak (0.0458), dan Pantai Pasir Panjang (0.0440). Sedangkan untuk wisata buatan, posisi pertama ditempati oleh Taman Nostalgia (0.0805), lalu diikuti oleh Bendungan Kali Dendeng (0.0801), Bendungan Bik'noi (0.0747), Museum Negeri Kupang (0.0731), dan Taman Kalpataru (0.0711). Dan pada wisata kuliner di Kota Kupang, nilai tertinggi atau posisi pertama adalah Kuliner Taman Nostalgia (0.0904), lalu diikuti Kuliner Jalan El Tari (0.0884), Kuliner Ikan Kua Asam (0.0884), Kuliner Oeba (0.0821), dan Kuliner Penfui (0.08037).

Pada awalnya, user akan diminta untuk mengisi nilai dari alternative. Pengisian ini mengikuti gradasi dari skala Likert yaitu 1 sampai 5, dimana nilai 1 dimulai dari sangat tidak penting sampai ke nilai 5 yang menyatakan bahwa hal tersebut sangat penting. Sedangkan untuk kriteria, nilai $\mathrm{W}$ adalah 50 untuk biaya, 90 untuk fasilitas dan 70 untuk review dari pengunjung tempat wisata tersebut. Hasil pengisian tersebut dan perhitungan akhir dapat dilihat pada table 1 untuk wisata alam, table 2 untuk wisata buatan dan table 3 untuk wisata kuliner.

Tabel 1 Hasil perhitungan 5 besar destinasi wisata alam dengan weighted product

\begin{tabular}{|c|c|c|c|c|c|}
\hline \multirow{3}{*}{ Altematif } & \multicolumn{3}{|c|}{ Kriteria } & \multirow[t]{3}{*}{ Nilai S } & \multirow[t]{3}{*}{ Nilai V } \\
\hline & Harga & Fasilitas & Review & & \\
\hline & 50 & 90 & 70 & & \\
\hline $\begin{array}{l}\text { Pantai Subasuka / } \\
\text { Flobamor }\end{array}$ & 1 & 5 & 3 & 2,8747 & 0,0519 \\
\hline Pantai Pasir Panjang & 2 & 5 & 3 & 2,4374 & 0,0440 \\
\hline Mata air Oelon & 1 & 4 & 3 & 2,6126 & 0,0471 \\
\hline Pantai Namosain & 1 & 4 & 4 & 2,8755 & 0,0519 \\
\hline Gua Monyet Alak & 1 & 3 & 4 & 2,5420 & 0,0458 \\
\hline
\end{tabular}

Table 2 Hasil perhitungan 5 besar destinasi wisata buatan dengan weighted product

\begin{tabular}{|l|r|r|r|r|r|}
\hline \multirow{3}{*}{ Alternatif } & \multicolumn{3}{|c|}{ Kriteria } & Nilai S & \multicolumn{1}{c|}{ Nilai V } \\
\cline { 2 - 4 } & Harga & Fasilitas & Raview & & \\
\cline { 2 - 4 } & 50 & 90 & 70 & & \\
\hline Bendungan Bik'noi & 2 & 4 & 4 & 2,4380 & 0,0747 \\
\hline $\begin{array}{l}\text { Bendungan Kali } \\
\text { Dendeng }\end{array}$ & 1 & 4 & 3 & 2,6126 & 0,0801 \\
\hline Taman Kalpataru & 2 & 3 & 5 & 2,3216 & 0,0711 \\
\hline Taman Nostalgia & 2 & 4 & 5 & 2,6263 & 0,0805 \\
\hline $\begin{array}{l}\text { Museum Negeri } \\
\text { Kupang }\end{array}$ & 3 & 4 & 5 & 2,3846 & 0,0731 \\
\hline
\end{tabular}

Tabel 3 Hasil perhitungan 5 besar destinasi wisata kuliner dengan weighted product

\begin{tabular}{|l|r|r|r|r|r|}
\hline \multirow{2}{*}{ Alternatif } & \multicolumn{3}{|c|}{ Kriteria } & Nilai S & Nilai V \\
\cline { 2 - 4 } & harga & fasilitas & review & & \\
\cline { 2 - 4 } & 50 & 90 & 70 & & \\
\hline $\begin{array}{l}\text { Kuliner } \\
\text { jalan El Tari }\end{array}$ & 3 & 5 & 5 & 2,6239 & 0,0884 \\
\hline $\begin{array}{l}\text { Kuliner } \\
\text { Penfui }\end{array}$ & 3 & 4 & 5 & 2,3846 & 0,0804 \\
\hline $\begin{array}{l}\text { Kuliner } \\
\begin{array}{l}\text { Taman } \\
\text { Nostalgia }\end{array}\end{array}$ & 2 & 5 & 4 & 2,6827 & 0,0904 \\
\hline $\begin{array}{l}\text { Kuliner } \\
\text { Oeba }\end{array}$ & 2 & 5 & 3 & 2,4374 & 0,0822 \\
\hline $\begin{array}{l}\text { Kuliner ikan } \\
\text { kua asam }\end{array}$ & 3 & 5 & 5 & 2,6239 & 0,0884 \\
\hline
\end{tabular}

Dari hasil tersebut diuji lagi ketahanan sistem (system robustness) dengan menggunakan analisis sensitivitas. Pada pengujian ini, nilai ketiga kriteria akan diturunkan masing-masing sebanyak 10 poin. Hasil dari pengujian menunjukkan bahwa nilai dari obyek wisata buatan dan obyek wisata kuliner tidak mengalami perubahan atau tahan terhadap perubahan jika nilai kriteria mengalami penurunan sebanyak 10 poin. Sedangkan untuk wisata alam, pantai Namosain akan berpindah ke posisi kedua dan pantai Subasuka akan naik ke posisi pertama. Untuk posisi yang lain tetap.

\section{SIMPULAN}

Simpulan yang diambil dari penelitian ini adalah dari tiga kriteria utama dalam rekomendasi destinasi wisata di Kota Kupang yaitu biaya, fasilitas yang ada dan juga review dari pengunjung yang pernah datang di tempat tersebut, serta destinasi wisata sebagai alternatif dari sistem, yaitu 55 lokasi wisata yang ada di Kota Kupang, dengan pembagian 27 obyek wisata alam, 15 wisata lain/buatan, serta 13 wisata kuliner, hasil perangkingan dengan WP, didapat 5 besar daerah lokasi wisata atau destinasi wisata tiap obyek wisata sebagai berikut

a. Untuk wisata alam : Pantai Namosain (0.0519), Pantai Subasuka (0.0519), Mata Air Oelon (0.0471), Gua Monyet 
alak (0.0458), dan Pantai Pasir Panjang (0.0440).

b. Untuk wisata buatan : Taman Nostalgia (0.0805), Bendungan Kali Dendeng (0.0801), Bendungan Bik'noi (0.0747), Museum Negeri Kupang (0.0731), dan Taman Kalpataru (0.0711).

c. Untuk wisata kuliner : Kuliner Taman Nostalgia (0.0904), Kuliner Jalan El Tari (0.0884), Kuliner Ikan Kua Asam (0.0884), Kuliner Oeba (0.0821), dan Kuliner Penfui (0.08037).

Dari hasil rangking tersebut, dilakukan pengujian analisis sensitivitas untuk menguji ketahanan sistem ketika terjadi perubahan, dalam hal ini adalah perubahan dalam nilai kriteria. Nilai kriteria pada pengujian kali ini akan diturunkan sebanyak 10 poin. Dari hasil pengujian, didapatkan bahwa perangkingan untuk obyek wisata alam terjadi perubahan posisi peringkat. Pantai Subasuka/Flobamor berpindah menjadi peringkat 1 dan Pantai Namosain berpindah ke peringkat 2. Untuk posisi lokasi wisata alam yang lain tetap pada posisi. Sedangkan untuk obyek wisata buatan dan wisata kuliner tidak terjadi perubahan ketika bobot kriteria diturunkan sebanyak 10 poin. Hal ini menunjukkan bahwa metode WP sangat tepat digunakan untuk melakukan perangkingan dalam sistem rekomendasi destinasi wisata yang ada di Kota Kupang karena tahan terhadap perubahan yang terjadi ketika kriteria diturunkan sebanyak 10 poin

\section{DAFTAR PUSTAKA}

[1] Badan Pusat Statistik Provinsi NTT [BPS]. 2019. Jumlah Wisatawan Domestik Menurut Kabupaten Kota di Provinsi NTT tahun 2010 - 2017. [internet][diunduh pada 2019 Mei 05]. Tersedia pada

https://ntt.bps.go.id/dynamictable/2018/ 09/06/785/jumlah-wisatawandomestikmenurut-kabupaten-kota-diprovinsi-nusa-tenggara-timur-20102017.html

[2] Badan Pusat Statistik Provinsi NTT [BPS]. 2019. Jumlah Wisatawan Mancanegara Menurut Kabupaten Kota di Provinsi NTT tahun 2006 - 2017. [internet][diunduh pada 2019 Mei 05]. Tersedia pada https://ntt.bps.go.id/dynamictable/2015 /03/17/54/jumlah-wisatawan- mancanegara-menurut-kabupaten-kotadi-provinsi-nusa-tenggara-timur-20062017.html

[3] Jaya P. 2013. Sistem Pendukung Keputusan Penentuan Bonus Karyawan Menggunakan Metode Weighted Product Studi Kasus PT Gunung Sari Medan. Pelita Informatika Budi Dharma. Vol 5 : hal 90-95. Medan [ID]]

[4] Rani S. 2014. Sistem Pendukung Keputusan Pemilihan Sepeda Motor berbasis Web dengan Metode Weighted Product. Pelita Informatika Budi Dharma. Vol 7 : hal 62-66. Medan[ID]

[5] Sari IK, Lulu DLW, Kartina DK. 2011. Sistem Pendukung Keputusan Penentuan Lokasi Gudang di Perusahaan dengan Metode Weighted Product. Politeknik Caltex Riau. Pekanbaru[ID] 